\title{
Organic cultivation of okra with ground cover of perennial herbaceous legumes
}

\author{
Diego Mathias N da Silva' ${ }^{1}$ Fábio Luiz Oliveira ${ }^{1}$; Paulo Henrique Grazziotti²; Claudenir Fávero²; Mateus \\ Augusto L Quaresma ${ }^{1}$ \\ 'UFES-CCA, DPV, C. Postal 16, 29500-000 Alegre-ES; diegoufvjm@yahoo.com.br; fabio.oliveira@cca.ufes.br; mateusveio@hotmail. \\ com; ${ }^{2}$ UFVJM-FCA, Campus JK, Rod. MG 367 km 583, 5000, Alto da Jacuba, 39100-000 Diamantina-MG; prufvjm@yahoo.com.br; \\ grazziot@yahoo.com.br
}

\begin{abstract}
The management of green manure with perennial herbaceous legumes has emerged as an interesting practice for vegetable production, improving the cultivation environment and increasing crop yields. In the present study we evaluated the organic okra cultivation in soil covered with perennial herbaceous legumes. The treatments consisted of okra grown in bare soil (control) or covered with tropical kudzo (Pueraria phaseoloides), perennial soybean (Glycine wightii), calopogonium (Calopogonium muconoides), Pinto peanut (Arachis pintoi) and Stylosanthes capitata and Stylosanthes macrocephala. A randomized block design with four replications was used. The weeding of legumes was realized before the okra was sown and this allowed the addition of quantities of dry matter, highlighting the potential of tropical kudzo $\left(3.74 \mathrm{t} \mathrm{ha}^{-1}\right)$, perennial soybean $\left(1.55 \mathrm{t} \mathrm{ha}^{-1}\right)$ and peanut $\left(1.30 \mathrm{tha}^{-1}\right)$. Okra cropped in soil covered with tropical kudzo and perennial soybean had the weed lowest dry matter accumulation until 150 days after sowing the okra. At 150 days after sowing the okra, only the areas covered with peanut and calopogonium had higher volumes of water in the soil compared to the control. Throughout the harvest, the okra plants grown in soil covered with perennial soybean and tropical kudzo showed the greatest heights. The maximum okra fruit yield $\left(16.23 \mathrm{t} \mathrm{ha}^{-1}\right)$ was obtained by growing okra in soil covered with perennial soybean.
\end{abstract}

Keywords: Abelmoschus esculentus, green manures, cover crops, soil management, sustainability.

\section{RESUMO}

Cultivo orgânico de quiabeiro em solo coberto com leguminosas herbáceas perenes

O manejo da adubação verde com leguminosas herbáceas perenes tem se apresentado como prática interessante à produção de hortaliças, proporcionando melhorias no ambiente de cultivo e aumentando a produtividade das culturas. Assim, o objetivo deste trabalho foi avaliar o cultivo orgânico de quiabeiro em solo coberto com leguminosas herbáceas perenes. Os tratamentos foram constituídos pelo cultivo do quiabeiro em solo descoberto (controle) ou coberto com cudzu tropical (Pueraria phaseoloides), soja perene (Glycine wightii), calopogônio (Calopogonium muconoides), amendoim forrageiro (Arachis pintoi) e estilosantes campo grande (Stylosanthes capitata e Stylosanthes macrocephala). O delineamento experimental foi de blocos ao acaso com quatro repetições. A roçada das leguminosas, realizada na véspera da semeadura do quiabeiro, possibilitou a adição de quantidades de massa seca às áreas de cultivo, destacando-se o potencial do cudzu tropical $\left(3,74 \mathrm{t} \mathrm{ha}^{-1}\right)$, soja perene $\left(1,55 \mathrm{t} \mathrm{ha}^{-1}\right) \mathrm{e}$ amendoim forrageiro $\left(1,30 \mathrm{tha}^{-1}\right)$. Nos cultivos de quiabeiro em solo coberto com cudzu tropical e com soja perene foram observados os menores acúmulos de massa seca de plantas espontâneas, até os 150 dias após a semeadura do quiabeiro. Aos 150 dias após a semeadura do quiabeiro, somente as áreas cobertas com amendoim forrageiro e com calopogônio apresentaram maiores volumes de água no solo em relação ao controle. Do início ao fim da colheita, as plantas de quiabeiro cultivadas em solo coberto com soja perene e com cudzu tropical apresentaram as maiores alturas. A produtividade máxima alcançada de frutos de quiabeiro $\left(16,23 \mathrm{tha}^{-1}\right)$, foi obtida no cultivo de quiabeiro em solo coberto com soja perene.

Palavras-chave: Abelmoschus esculentus, adubação verde, plantas de cobertura, manejo do solo, sustentabilidade.

(Recebido para publicação em 24 de julho de 2012; aceito em 22 de julho de 2013)

(Received on July 24, 2012; accepted on July 22, 2013)

$\mathrm{O}$ kra (Abelmoschus esculentus) is characterized by a short cycle, early production, relatively long harvest period, pest and disease resistance and heat tolerance. It is a vegetable with high nutritive value, easy to cultivate, profitable and relatively lowcost (Oliveira et al., 2003; Ribas et al., 2003; Filgueira, 2008; Sediyama et al.,
2009). Due to these factors, the okra has been cultivated mainly by family and organic producers (Ribas et al., 2003).

Okra growth, production and quality are related to fertilizer application, especially organic fertilization, that has various benefits including improvement in the physical, chemical and biological attributes of the soil (Oliveira et al.,
2003; Souza, 2003; Ribas et al., 2003). Thus green manure with legumes is a significant alternative, because it retains moisture, incorporates organic matter and nitrogen and recycles nutrients in the deeper layers of the soil. Other benefits include partial replacement of chemical fertilization and consequently it contributes to the sustainability of the 
productive system (Oliveira et al., 2003; Ribas et al., 2003; Teodoro et al., 2011).

Among ways of managing green manure with legumes, intercropping with the crop of economic interest can promote increase in vegetable productivity (Oliveira et al., 2003) without paralyzing productive areas for a period. This form of green manure management is an important factor for the adoption of this practice by family farmers (Ribas et al., 2003), especially in the semiarid regions where the rainy season is concentrated in a few months of the year, when short cycle crop production is concentrated.

A possibility for intercropping would be using live cover with perennial herbaceous legumes in areas with vegetables. A study carried out with lettuce and green beans cropped in soil with live pinto peanut cover showed that this practice can substitute cropping these vegetables alone in beds and favors greater protection for the soil while maintaining the crop and yield (Oliveira, 2006a, 2006b). Intercropping of malagueta pepper with the perennial legumes Calopogonium mucunoides and tropical kudzo (Pueraria phaseoloides), weeded at 100 days after sowing, resulted in yields similar to those obtained when 120 and $240 \mathrm{~kg} \mathrm{ha}^{-1}$ nitrogen were applied (Santos et al., 2004).

Some studies have been carried out with okra intercropped with green manure, using annual legumes. Intercropping with Crotalaria juncea resulted in an increase of up to $30 \%$ in okra fruit yield, increase in accumulated nitrogen in the leaves and less incidence of root galls due to Meloidogyne spp. (Ribas et al., 2003). According to estimates by these authors, nitrogen exported through collected okra fruit would have been compensated by its entry by biological fixing and thus the green manure in terms of intercropping with $C$.juncea would be viable especially for organic production units where the use is neither recommended or tolerated of synthetic nitrogenated fertilizers. Tivelli et al. (2011) emphasized that the production system of the okra intercropped with low stand green manures can be used without damage to okra production and with the benefits of green manure.

Introducing legumes in the productive system can bring benefits such as improvement of the physical characteristics of the soil, including aggregation and implementation of organic carbon, increased biomass, nutrient recycling, nitrogen supplied by biological fixing, soil moisture maintenance, decrease in maximum temperatures and heat amplitude, permanent protection against the main soil degrading agents and weed control (Perin et al., 2000; Perin et al., 2002; Primavesi, 2002; Espíndola et al., 2006; Duarte Júnior \& Coelho, 2008; Furlani et al., 2008; Teodoro et al., 2011).

Using green manure with perennial herbaceous legumes may be an important strategy for vegetable production. However, it is important to generate more information so that producers in different locations can adopt the practice.

Thus the objective of the present study was to assess organic okra cropped in soil covered with perennial herbaceous legumes.

\section{MATERIAL AND METHODS}

The study was carried out from December 2008 to April 2011 in the experimental area at the Jacaré Family Agricultural College (Escola Família Agrícola de Jacaré), in Itinga, Minas Gerais state, Brazil (16 28'04'S, $41^{\circ} 59^{\prime} 50^{\prime} \mathrm{W}, 672 \mathrm{~m}$ altitude), in the region of the Caatinga (tropical thorn forest) biomass in the Mid Jequitinhonha Valley. According to the meteorological station at Itaobim, the closest to the experiment, in the experimental period the accumulated rainfall was 722 $\mathrm{mm}$, the mean minimum temperature was $20.8^{\circ} \mathrm{C}$ and the mean maximum temperature was $32.4^{\circ} \mathrm{C}$.

The treatments consisted of cultivating okra in bare soil (control) or soil covered with the perennial herbaceous legumes tropical kudzo (Pueraria phaseoloides), perennial soybean (Glycine wightii), Calopogonium mucunoides, pinto peanut (Arachis pintoi) and Stylosanthes
(Stylosanthes capitata andStylosanthes macrocephala). A randomized block design was used with four replications.

The legumes were sown in December 2008 at a depth of $2 \mathrm{~cm}$, between drill spacing $40 \mathrm{~cm}$, with an average density of 20 seeds per drill meter. They were weeded at the soil level before sowing the okra (720 days after sowing the legumes) at the end of November 2010, and the plant matter was left on top of the soil as a form of green manure.

The soil of the area is yellow argissol with $64 \%$ sand, $10 \%$ silt and $26 \%$ clay in the 0 to $20 \mathrm{~cm}$ layer. The legumes were at 720 days of cycle and so the chemical analyses were carried out in the 0 to 5 $\mathrm{cm}$ layer of the soil separately in each area occupied by the different legumes (Table 1).

The experimental unit consisted of three $2 \mathrm{~m}$ planting rows with 1.0 $\mathrm{m}$ between-row spacing and $0.25 \mathrm{~m}$ between-plant spacing in a total of 8 okra plants per planting row. However, only the plants in the central row, with the exception of the borders, were used for data collection, that is, the useful area consisted of the six central plants of each plot.

Hill plots were made following the required spacing and $400 \mathrm{~g}$ cattle manure were placed in each one, that represented half the organic planting fertilization recommended for the okra (Souza, 2003). The cattle manure contained the following nutrients: 10.14 $\mathrm{g} \mathrm{kg}^{-1} \mathrm{~N}, 0.76 \mathrm{~g} \mathrm{~kg}^{-1} \mathrm{P}, 2.28 \mathrm{~g} \mathrm{~kg}^{-1} \mathrm{~K}, 1.29$ $\mathrm{g} \mathrm{kg}^{-1} \mathrm{Ca}$ and $0.66 \mathrm{~g} \mathrm{~kg}^{-1} \mathrm{Mg}$. Later the okra cultivar Santa Cruz 47 was sown, using four seeds per hill plot, thinned 20 days after sowing and one plant was kept per hill plot. Seed dormancy was broken by immersion in water for 24 hours the day prior to sowing (Filgueira, 2008).

The fresh matter supply from weeding the legumes was quantified and a sample of approximately 100 $\mathrm{g}$ was removed to determine its dry matter and nutrient concentrations (Malavolta et al., 1989) after drying the fresh matter in a chamber with forced air ventilation at $65^{\circ} \pm 2^{\circ} \mathrm{C}$, until constant mass. In the chemical analyses of the plant materials, the $\mathrm{N}$ content was determined after sulfuric digestion and distillation in Kjeldahl; the P, K, Ca and 
$\mathrm{Mg}$ contents were determined after nitric perchlorate digestion. $\mathrm{P}$ was determined in a spectrophotometer, $\mathrm{K}$ by flame photometry and $\mathrm{Ca}$ and $\mathrm{Mg}$ by atomic absorption spectrophotometer.

Starting at the time when the legumes were weeded, the okra crop was in parallel to the legume sprouting. The legume sprouting capacity after weeding was quantified by the rate of live soil coverage, determined after 110 days, using the number of intersections method. This consisted of a one square meter wooden frame containing a 10 $\mathrm{cm}$ mesh string net that defined 100 points and the cover was read directly in percent. The weed dry matter was determined in the central area of the plots in $1 \mathrm{~m}^{2}$, at 20,50 and 110 days after sowing the okra (DAS). The dry matter was quantified after drying in a forced air ventilation chamber at $65^{\circ} \pm 2^{\circ} \mathrm{C}$ until constant mass. After each assessment, the weeds from all the plots were removed manually and with the help of a hoe and left on top of the soil.

The volumetric moisture of the 0 to $5 \mathrm{~cm}$ soil layer was determined on January 17 (50 DAS) and April 292011 (150 DAS). The first assessment of the water volume removed from the soil was in the dry period of the wet season, when the crops were most vulnerable to water shortage and the second assessment was at the end of the rainy season. The volume of water in the soil was determined indirectly by the apparent soil density, using the chamber standard (Bernardo et al., 2006).

The okra height was assessed during the harvest period (Sediyama et al., 2009), at 80, 110 and 150 DAS, using the mean of the values collected from the six central plants from each plot using a tape measure. The following were also assessed: mean mass, fruit number and yield during the harvests carried out between 80 and 150 DAS. Two collections were made per week during this period.

The statistical analyses were carried out using the SISVAR statistical program (Ferreira, 1998). The data were submitted to analysis of variance by the F test at $5 \%$ probability. The significant means were compared by the Tukey test at $5 \%$ probability.

\section{RESULTS AND DISCUSSION}

The okra was sown at the start of the rainy season in the region and although the period with available water was short for the legumes to sprout after the drought, weeding at the soil level the day before the okra was sown added quantities of dry matter to the cropping areas (Table 2). This green fertilization meant the delivery of macronutrients, highlighting the potential of tropical kudzo, perennial soybean and pinto peanut.

Parallel to the okra cultivation, the legumes Calopogonium mucunoides, pinto peanut and perennials soybean re-established themselves best after the weeding (Table 3). At 110 days after the weeding, the Calopogonium mucunoides presented $95.3 \%$, pinto peanut $95.0 \%$ and perennial soybean, $33.3 \%$ green cover of the soil. The capacity of the perennial legumes to re-establish after weeding management is relevant, especially when considering the field with permanent soil cover, when it is expected that the legumes remain in the system, maintaining the benefits of their company with the crops.

It is emphasized that tropical kudzo presented 19.5 live cover of the soil at 110 days after the cut (Table 3), that was due to the stress caused by weeding at soil level, that damaged the re-establishment and badly affected sprouting of the species. The Stylosanthes presented $0 \%$ live soil cover, that is, they did not sprout showing it was a species with less potential for re-establishment after weeding at soil level. Thus it can be stated that management with weeding of perennial legumes used as permanent plant soil cover in crops is a practice that still needs study, because apparently each legume would need a different cutting time and height.

Twenty days after sowing the okra (DAS), smaller weed dry matter accumulations were observed in the areas of okra cropped in soil covered with tropical kudzo, perennial soybean or pinto peanut (Table 3 ), probably because the greater dead cover provided after weeding these legumes the day before sowing the okra. The areas cropped on soil covered with tropical kudzo or perennial soybean were among those with the lowest weed presence until 110 DAS that was probably due to root excretions, chemical and physical modification of the soil, shading and lixiviated extract of the weeded material of these legumes, that may promote suppressive and allelopathic effects (Primavesi, 2002; Severino \& Christoffoleti, 2004).

Generally, the greatest accumulation

Table 1. Results of chemical analyzes of the soil, on a $0-5 \mathrm{~cm}$ depth layer, from the areas occupied by perennial herbaceous legumes, 720 days after sowing date (resultados das análises químicas dos solos, na camada de 0 a $5 \mathrm{~cm}$ de profundidade, das áreas ocupadas por leguminosas herbáceas perenes aos 720 dias após a semeadura). Itinga, UFVJM, 2010/2011.

\begin{tabular}{|c|c|c|c|c|c|c|c|c|c|c|}
\hline \multirow{2}{*}{ Legumes } & \multirow{2}{*}{$\begin{array}{c}\mathbf{p H} \\
\text { (water) }\end{array}$} & P (Mehlich) & $\mathbf{K}$ & $\mathbf{C a}$ & $\mathrm{Mg}$ & $\mathbf{H}+\mathbf{A l}$ & SB & $\mathbf{t}$ & \multirow{2}{*}{$\begin{array}{c}V \\
(\%)\end{array}$} & \multirow{2}{*}{$\begin{array}{c}\mathrm{MO} \\
\left(\mathrm{g} / \mathbf{d m}^{3}\right)\end{array}$} \\
\hline & & \multicolumn{2}{|c|}{$\mathrm{mg} / \mathrm{dm}^{3}$} & \multicolumn{5}{|c|}{$\mathrm{cmol}_{\mathrm{c}} / \mathrm{dm}^{3}$} & & \\
\hline Tropical kudzo & 6.2 & 57.7 & 279.3 & 2.9 & 1.3 & 2.4 & 4.9 & 4.9 & 67.3 & 14 \\
\hline Calopogonium & 6.4 & 51.8 & 321.4 & 3.8 & 1.6 & 2.3 & 6.3 & 6.3 & 73.0 & 20 \\
\hline Pinto peanut & 6.6 & 67.4 & 265.0 & 3.7 & 1.0 & 1.5 & 5.3 & 5.4 & 78.3 & 18 \\
\hline Perennial soybean & 6.6 & 55.0 & 327.4 & 3.2 & 1.3 & 2.7 & 5.3 & 5.3 & 66.8 & 16 \\
\hline Stylosanthes & 6.6 & 59.4 & 187.2 & 3.3 & 0.7 & 1.5 & 4.5 & 4.5 & 75.0 & 14 \\
\hline Control & 6.9 & 59.9 & 416.0 & 3.4 & 0.4 & 1.4 & 4.9 & 4.9 & 75.3 & 19 \\
\hline
\end{tabular}


Table 2. Dry mass and macronutrients of the aboveground part of perennial herbaceous leguminous plants, 720 days after weeding, used as soil mulch (massa seca e macronutrientes da parte aérea de leguminosas herbáceas perenes aos 720 dias após a semeadura, roçadas e usadas como cobertura morta do solo). Itinga, UFVJM, 2010/2011.

\begin{tabular}{lcrrrrr}
\hline \multirow{2}{*}{ Legumes } & $\begin{array}{c}\text { Dry mass } \\
(\mathbf{t} / \mathbf{h a} \mathbf{n})\end{array}$ & $\mathbf{N}$ & $\mathbf{P}$ & $\mathbf{K}$ & $\mathbf{C a}$ & $\mathbf{M g}$ \\
\cline { 3 - 8 } & $3.74 \mathrm{a}^{1}$ & $101 \mathrm{a}$ & $7.2 \mathrm{a}$ & $60 \mathrm{a}$ & $37 \mathrm{a}$ & $36 \mathrm{a}$ \\
\hline Tropical kudzo & $1.55 \mathrm{~b}$ & $38 \mathrm{~b}$ & $3.2 \mathrm{~b}$ & $28 \mathrm{~b}$ & $20 \mathrm{~b}$ & $15 \mathrm{~b}$ \\
Perennial soybean & $1.30 \mathrm{bc}$ & $32 \mathrm{bc}$ & $2.3 \mathrm{~b}$ & $25 \mathrm{~b}$ & $16 \mathrm{bc}$ & $12 \mathrm{~b}$ \\
Pinto peanut & $1.30 \mathrm{~cd}$ & $14 \mathrm{~cd}$ & $1.8 \mathrm{bc}$ & $11 \mathrm{c}$ & $9 \mathrm{~cd}$ & $4 \mathrm{c}$ \\
Stylosanthes & $0.78 \mathrm{~cd}$ & $7 \mathrm{~d}$ & $0.6 \mathrm{c}$ & $4 \mathrm{c}$ & $4 \mathrm{~d}$ & $2 \mathrm{c}$ \\
Calopogonium & $0.27 \mathrm{~d}$ & 22.5 & 21.7 & 22.4 & 22.2 & 22.8 \\
\hline CV (\%) & 24.2 & 22.05 &
\end{tabular}

${ }^{1}$ Values followed by same letters in columns do not differ by Tukey test, $\mathrm{p}<0.05$ (valores seguidos de letras iguais, nas colunas, não diferem entre si pelo teste Tukey, $\mathrm{p}<0,05$ ).

Table 3. Living mulch of the soil (\%) with perennial herbaceous legumes, 110 days after weeding; dry mass of weeds in cultivation of okra with soil cover of perennial herbaceous legumes (cobertura viva do solo (\%) com leguminosas herbáceas perenes aos 110 dias após a roçada e massa seca de plantas espontâneas em cultivo de quiabeiro em solo coberto com leguminosas herbáceas perenes). Itinga, UFVJM, 2010/2011.

\begin{tabular}{lcccc}
\hline \multirow{2}{*}{ Legumes } & $\begin{array}{c}\text { Living mulch } \\
\text { of the soil (\%) }\end{array}$ & \multicolumn{3}{c}{ Dry mass of spontaneous plants (t/ha) } \\
\cline { 3 - 6 } & $19.5 \mathrm{c}^{2}$ & $0.08 \mathrm{c}$ & $0.46 \mathrm{~d}$ & $0.05 \mathrm{e}$ \\
\hline Tropical kudzo & $33.3 \mathrm{~b}$ & $0.10 \mathrm{c}$ & $0.82 \mathrm{~cd}$ & $0.09 \mathrm{de}$ \\
Perennial soybean & $94.0 \mathrm{a}$ & $0.22 \mathrm{c}$ & $1.34 \mathrm{bc}$ & $0.52 \mathrm{a}$ \\
Pinto peanut & $0.0 \mathrm{~d}$ & $0.59 \mathrm{~b}$ & $1.85 \mathrm{ab}$ & $0.34 \mathrm{bc}$ \\
Stylosanthes & $95.3 \mathrm{a}$ & $0.96 \mathrm{a}$ & $1.92 \mathrm{ab}$ & $0.24 \mathrm{~cd}$ \\
Calopogonium & - & $0.83 \mathrm{ab}$ & $2.17 \mathrm{a}$ & $0.50 \mathrm{ab}$ \\
Control & 11.0 & 31.0 & 18.0 & 25.1 \\
\hline CV $(\%)$ & &
\end{tabular}

${ }^{1} \mathrm{DAS}=$ days after sowing of okra (dias após a semeadura); ${ }^{2}$ Values followed by same letters in columns do not differ by Tukey test, $\mathrm{p}<0.05$ (valores seguidos de letras iguais, nas colunas, não diferem entre si pelo teste Tukey, $\mathrm{p}<0,05)$.

of spontaneous plant dry matter was observed at 50 DAS (Table 3). This may have been due to the decrease in the dead soil cover caused by the decomposition of the plant matter from weeding the legumes the day before sowing the okra, that favored weed presence. Although the Calopogonium mucunoides reestablished well after the weeding and, consequently, gave greater soil cover (Table 3 ). High weed dry matter accumulation was observed at 50 DAS in the okra crop in soil covered with this legume, that may have been related to the greater soil moisture present in this area (Figure 1).

The smallest accumulation of spontaneous plant dry matter was observed at 110 DAS (Table 3), with the exception of the cropping in soil covered and pinto peanut (Table 2), also most induced reduction in weed dry matter at 20 and 50 DAS (Table 3). Studies have shown the benefits of dead cover management with legume residues in organic carrot cultivation, where this practice efficaciously reduced weed presence in the area (Santos et al., 2011). Generally, the smaller weed presence in the area of soil covered with the perennial herbaceous legumes showed the importance of their management as soil cover for the crops, contributing to labor lower costs for weed control.

At 50 DAS, all the areas of okra cultivated in soil covered with the legumes presented higher volumes of water in the soil compared to the area with bare soil (control), except for that with Stylosanthes. However, at 150 DAS, the volume of the water in the soil was greater only in the areas with okra cultivated in soil covered with pinto peanut and Calopogonium mucunoides than that in the area with bare soil (Figure 1). This was probably due to the better re-establishment of these species after weeding that promoted greater soil cover and consequently reduced evaporation. In these areas, the residues of the weeded legume matter, added to the growing live matter, by covering the soil surface, constituted a physical barrier to the transference of energy and water vapor between the soil and the atmosphere (Strecket al., 1994), that was reflected in a greater capacity to maintain moisture in the soil. The plant residues retained water in their structure, releasing it gradually to the soil and leaving it more moist in the surface layer that was in direct contact with the residues (Oliveira \& Souza, 2003).

It is pointed out that in tropical climates the water transpired by crops is often less than that evaporated directly from the soil (Primavesi, 2002). Therefore using cover plants in agricultural crops optimizes productive resources, especially water, the main limiting resource to agricultural activity in the Mid Jequitinhonha Valley (Oliveira et al., 2002). Furthermore, the surface of soil without vegetation can be encrusted by rain and with this erosion and surface water run-off would be more intense than in soil covered by 
Table 4. Average weight, number of fruits and yield of okra grown under soil covered with perennial herbaceous legumes (massa média, número de frutos e produtividade do quiabeiro cultivado em solo coberto com leguminosas herbáceas perenes). Itinga, UFVJM, 2010/2011.

\begin{tabular}{|c|c|c|c|}
\hline Legumes & $\begin{array}{c}\text { Average fruit } \\
\text { weight (g) }\end{array}$ & $\begin{array}{c}\text { Number of } \\
\text { fruits/ha }\left(\times 10^{3}\right)\end{array}$ & $\begin{array}{l}\text { Yield } \\
\text { (t/ha) }\end{array}$ \\
\hline Tropical kudzo & $14.9 \mathrm{ab}^{1}$ & $863.3 \mathrm{~b}$ & $12.86 \mathrm{~b}$ \\
\hline Perennial soybean & $15.9 \mathrm{a}$ & $1,023.3 \mathrm{a}$ & $16.23 \mathrm{a}$ \\
\hline Pinto peanut & $14.2 \mathrm{ab}$ & $591.7 \mathrm{~d}$ & $8.38 \mathrm{c}$ \\
\hline Stylosanthes & $13.8 \mathrm{~b}$ & $955.0 \mathrm{ab}$ & $13.14 \mathrm{~b}$ \\
\hline Calopogonium & $15.0 \mathrm{ab}$ & $678.3 \mathrm{~cd}$ & $10.19 \mathrm{c}$ \\
\hline Control & $13.9 \mathrm{ab}$ & $725.0 \mathrm{c}$ & $10.06 \mathrm{c}$ \\
\hline CV (\%) & 6.2 & 5.1 & 8.3 \\
\hline
\end{tabular}

${ }^{1}$ Values followed by same letters in columns do not differ by Tukey test, $\mathrm{p}<0.05$ (valores seguidos de letras iguais, nas colunas, não diferem entre si pelo teste Tukey, $p<0,05$ ).

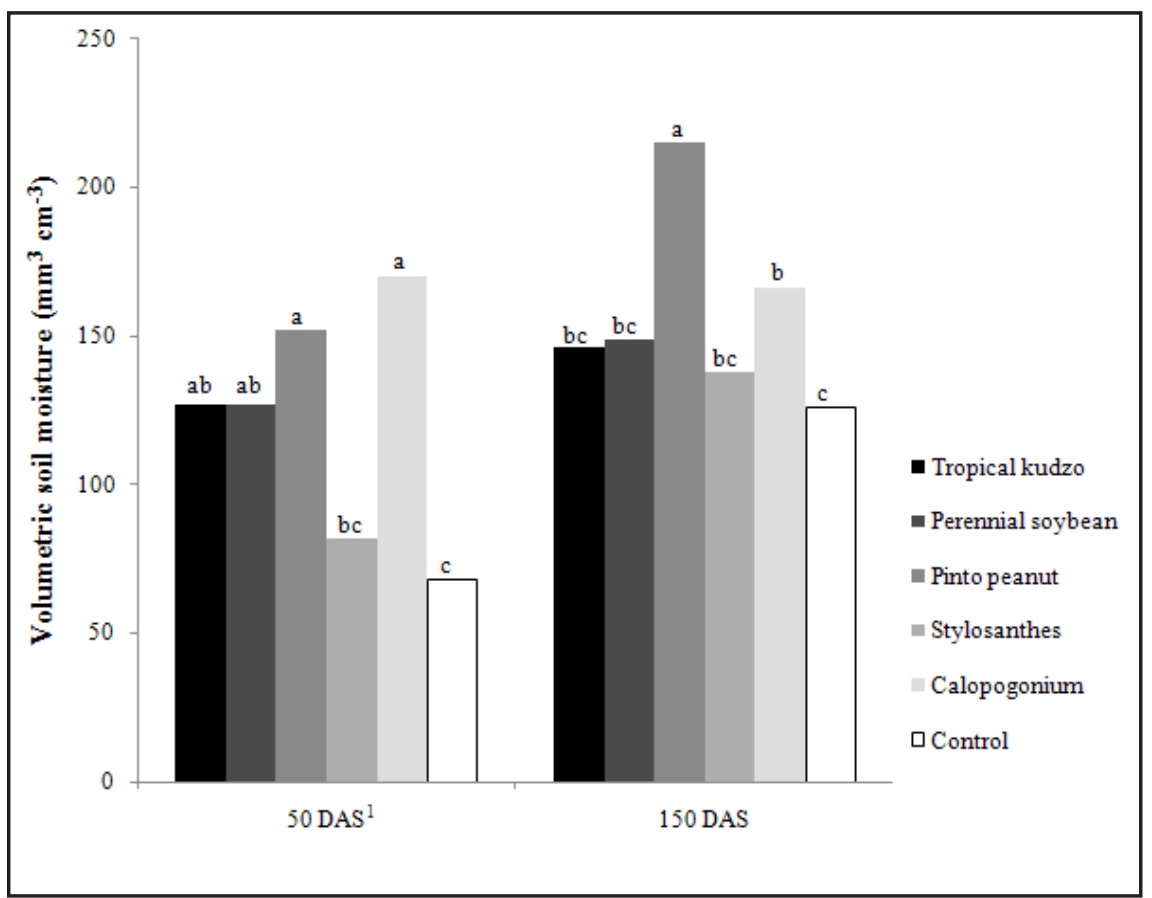

Figure 1. Volumetric soil moisture for okra cultivation under ground coverage using perennial herbaceous legumes (umidade volumétrica do solo em cultivo de quiabeiro em solo coberto com leguminosas herbáceas perenes); Values followed by same letters in columns do not differ by Tukey test, $\mathrm{p}<0.05$ (valores seguidos de letras iguais, nas colunas, não diferem entre si pelo teste Tukey, $\mathrm{p}<0,05)^{1} \mathrm{DAS}$ : Days after sowing of okra (dias após a semeadura do quiabeiro). Itinga, UFVJM, 2010/2011.

vegetation (Primavesi, 2002).

The greater water retention in the soil where the okra was cropped in soil covered with pinto peanut and the soil moisture similar to the crop in bare soil (control) in the area under tropical kudzo at 150 DAS (Figure 1) did not corroborate the results obtained in these two legumes intercropped with banana cultivated in Seropédica-RJ (Perin et al., 2004). The authors showed that the greatest moisture retention in the soil in areas with tropical kudzo was due to the greater protection of the soil surface by a thick layer of residues from natural leaf senescence, while in the area with pinto peanut the lower natural leaf dehiscence resulted in a thinner layer of residues that allowed a higher water evaporation rate from the soil, thus decreasing the moisture contents.

At 50 DAS the areas with pinto peanut and tropical kudzo presented similar soil moisture; however, at 150 DAS the soil with tropical kudzo presented a lower volume of accumulated water than that with pinto peanut (Figure 1). This result may have been due to the lower capacity of tropical kudzo to sprout after weeding and thus to provide live soil cover (Table 3).

At 80 DAS, the height of the okra cultivated in the soil covered with perennial soybean, tropical kudzo and Stylosanthes was greater than that of okra cultivated in bare soil (control), that presented the lowest height and did not differ from okra cultivated in the soil covered with the other legumes (Figure 2).

At 110 DAS, the greatest okra heights were observed in the okra cultivated in soil covered with perennial soybean and tropical kudzo. No difference was observed in soil covered with the other legumes that were taller than the okra cultivated in bare soil (Figure 2).

At 150 DAS, no differences were observed in the height of the okra cultivated in soil covered with the legumes, but again, the height of the okra cultivated in soil covered with perennial soybean and tropical kudzo was higher than the okra cultivated in bare soil (control), that showed the lowest height (Figure 2). This characteristic is important because okra height correlates highly with fruit yield (Sediyama et al., 2009).

An interesting fact is that the okra cultivated in bare soil was attacked more by leaf cutting ants at the start of its cycle and the attacks were less intense in the okra cultivated in soil covered with the different legumes. Cropping in soil covered with the legumes resulted in possible food offer for the ants, bearing in mind that they also cut and carried the legume leaves and thus attacked the okra leaves less severely.

There was no gain in mean okra fruit mass in soil covered with legumes; on the contrary, there was reduction when covered with Stylosanthes compared to cultivation in bare soil (control) (Table 4). However, there was an increase in the number of fruits in soil covered with perennial soybean, Stylosanthes and tropical kudzo compared to the bare soil (control) that reflected in the okra yield that was greater in the areas 


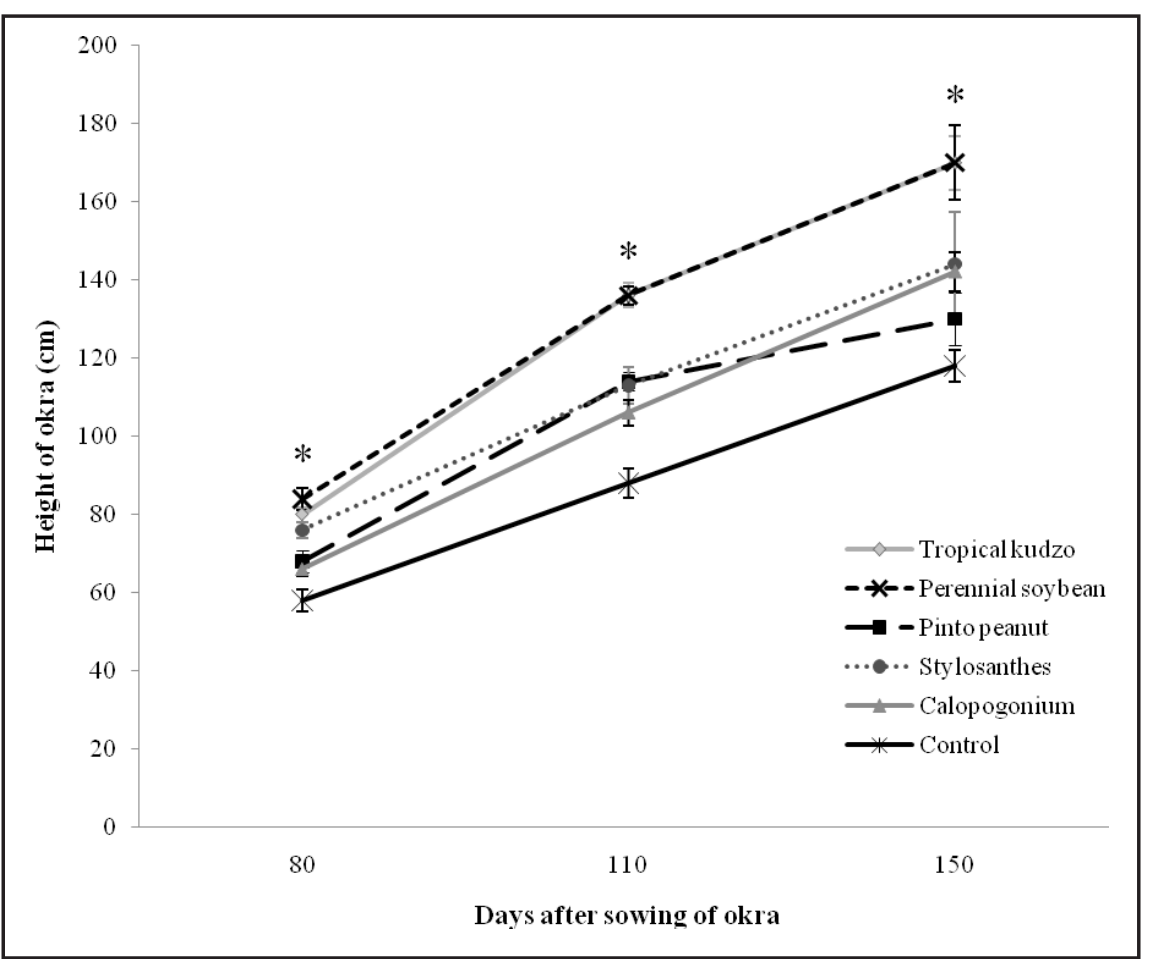

Figure 2. Height of okra grown under soil coverage with perennial herbaceous legumes. Means followed by an asterisk are significantly different for that time of sampling, by Tukey test, $5 \%$ probability (altura do quiabeiro cultivado em solo coberto com leguminosas herbáceas perenes. Médias seguidas por asterisco são significativamente diferentes para aquela época de amostragem, pelo teste de Tukey a 5\% de probabilidade). Itinga, UFVJM, 2010/2011.

with these legumes. Fruit yields were observed of 16.23 t ha $^{-1}$ when cultivating in soil covered with perennial soybean, 13.14 tha $^{-1}$ with Stylosanthes and 12.86 $\mathrm{t} \mathrm{ha}^{-1}$ with tropical kudzo, representing yield increases of $61.3,30.6$ and $27.8 \%$, respectively, compared to cultivation in bare soil (Table 4).

Although the okra cultivated in soil covered with tropical kudzo received the greatest volume of dry matter when this legume was weeded, that meant greater nutrient supplies (Table 2), did not result in greater okra yield (Table 4). This result may have been related to the type of green manure management.

Weeding tropical kudzo the day before sowing the okra may have supplied a large quantity of nutrients, with the residue decomposition, only at the start of the crop cycle, that is also valid for the Stylosanthes. Furthermore, these legumes seem to not withstand the weeding at soil level that delayed their capacity to form another live cover (Table 3 ) and consequently their capacity to contribute to water storage in the soil (Figure 1). A thinner live the region of the Atlantic rainforest have shown this response of pinto peanut to conditions of water shortage, including reports that under conditions of prolonged shortage, live cover with pinto peanut may effectively promote competition for water with the main crop (Perin et al., 2002).

These results highlight the need to adjust management of perennial herbaceous legumes, especially for weeding height and time, to improve compatibility with the okra crop.

Generally, the yields obtained were similar to those reported in other studies, although that of the okra has been shown to vary in function of the harvest period and fertilization used. A normal yield for the crop is around 15-20 t ha h $^{-1}$ (Filgueira, 2008) and different from that reported by Galati (2010), around $12 \mathrm{tha}^{-1}$. With the Santa Cruz 47 cultivar, Ferreira et al. (2001) obtained maximum yield of $13.13 \mathrm{tha}^{-1}$ in the northern region of Rio de Janeiro state, while Rizzo et al. (2001) obtained $8.74 \mathrm{tha}^{-1}$ in the region of Jaboticabal, São Paulo state. Oliveira et al. (2003) obtained maximum yield of $16.70 \mathrm{t}$ $\mathrm{ha}^{-1}$ with the application of $141 \mathrm{~kg} \mathrm{ha}^{-1}$ nitrogen in the region of Areia, Paraiba state. With the same cultivar, Ribas et al. (2003), in the region of Seropédica, Rio de Janeiro state, obtained maximum yield of $30.81 \mathrm{t} \mathrm{ha}^{-1}$ with cattle manure application and intercropping with Crotalaria juncea while Souza (2012) obtained maximum yield of $10.05 \mathrm{tha}^{-1}$ in the region of Itabaiana, Sergipe state using organic and chemical fertilization and Crotalaria juncea incorporation.

Concluding, in the conditions of this research, perennial soybean constitutes the best soil cover for organic okra cultivation, because it resulted in greater fruit yield.

\section{ACKNOWLEDGEMENTS}

The authors thank CAPES for the MSc grant to the first author and the $\mathrm{CNPq}$ and MDA/SAF, for funding the research. They also thank the Escola Família Agrícola de Jacaré, the Federal University of the Vales do Jequitinhonha and Mucuri for the 
support and infrastructure necessary to carry out the experiment and the National Meteorology Institute (Instituto Nacional de Meteorologia) for the meteorological data.

\section{REFERENCES}

BERNARDO S; SOARES AA; MANTOVANI EC. 2006. Manual de Irrigação. Viçosa: UFV. $625 \mathrm{p}$.

DUARTE JUNIOR JB; COELHO FC. 2008. Adubos verdes e seus efeitos no rendimento da cana-de-açúcar em sistemas de plantio direto. Bragantia 67: 723-732.

ESPINDOLA JAA; GUERRA JGM; PERIN A; TEIXEIRAMG;ALMEIDADL; URQUIAGA S; BUSQUET RNB. 2006. Bananeiras consorciadas com leguminosas herbáceas perenes utilizadas como cobertura vivas. Pesquisa Agropecuária Brasileira 41: 415 420.

FERREIRA DF. 1998. Sisvar: sistema de análise de variância para dados balanceados. Lavras: UFLA. 19p.

FERREIRA JM; CAETANO LCS; ANDRADE WEB; VALENTINI L; RIBEIRO LJ; SILVA MFS. 2001. Adubação orgânica e mineral em hortaliças no Norte Fluminense: cultura do quiabeiro. In: CONGRESSO BRASILEIRO DE OLERICULTURA, 41. Resumos... Brasília: SOB (CD-ROM).

FILGUEIRA FAR. 2008. Novo manual de olericultura: agrotecnologia moderna na produção e comercialização de hortaliças. Viçosa: UFV. 421p.

FURLANI CEA; GAMERO CA; LEVIEN R; SILVA RP; CORTEZ JW. 2008. Temperatura do solo em função do preparo do solo e do manejo da cobertura de inverno. Revista Brasileira de Ciência do Solo 32: 375-380.

GALATI VC. 2010. Crescimento e acúmulo de nutrientes em quiabeiro "Santa Cruz 47". Jaboticabal: UNESP. 26p (Tese mestrado).

MALAVOLTA E; VITTI GC; OLIVEIRA SA 1989. Avaliação do estado nutricional de plantas, princípios e aplicações. Piracicaba: POTAFOS. 201p.

MOREIRA FMS; SIQUEIRA JO. 2002. Microbiologia e bioquímica do solo. Lavras: UFLA. $626 \mathrm{p}$.

OLIVEIRA FR; DUARTE U; MENEGASSE LN. 2002. Levantamento hidrológico da área de
Araçuaí no médio vale do Jequitinhonha-MG. Revista Águas Subterrâneas 16: 39-56.

OLIVEIRAAP; ALVES AU; DORNELAS CSM; SILVA JA; PÔRTO ML; ALVES AU. 2003. Rendimento de quiabo em função das doses de nitrogênio. Acta Scientiarum Agronomy 25: 265-268.

OLIVEIRA CAP; SOUZA CM. 2003. Influência da cobertura morta na umidade, incidência de plantas daninhas e de broca-do-rizoma (Cosmopolites sordidus) em um pomar de bananeiras (Musa ssp). Revista Brasileira de Fruticultura 25: 345-347.

OLIVEIRA FL; RIBAS RGT; JUNQUEIRA RM; PADOVAN MP; GUERRA JGM; ALMEIDA DL; RIBEIRO RLD. 2003. Uso do pré-cultivo de Crotalaria juncea e de doses crescentes de cama-de-aviário na produção do repolho sob manejo orgânico. Agronomia 37: 60-63.

OLIVEIRA NG; DE-POLLI H; ALMEIDA DL; GUERRA JGM. 2006a. Feijão-vagem semeado sobre cobertura viva perene de gramínea e leguminosa e em solo mobilizado, com adubação orgânica. Pesquisa Agropecuária Brasileira 41: 1361-1367.

OLIVEIRA NG; DE-POLLI H; ALMEIDA DL; GUERRA JGM. 2006b. Plantio direto de alface adubada com "cama" de aviário sobre coberturas vivas de grama e amendoim forrageiro. Horticultura Brasileira 24: 112117.

PERIN A; TEIXEIRA MG; GUERRA JGM. 2000. Desempenho de algumas leguminosas com potencial para utilização como cobertura permanente de solo. Agronomia 34: 38-43.

PERIN A; GUERRA JGM; TEIXEIRA MG; PEREIRA MG; FONTANA A. 2002. Efeito da cobertura viva com leguminosas herbáceas perenes na agregação de um argissolo. Revista Brasileira de Ciência do Solo 26: 713-720.

PERIN A; LIMA EA; ESPINDOLA JAA; GUERRA JGM; TEIXEIRA MG; BUSQUET RNB. 2002. Contribuição da cobertura viva de solo com leguminosas herbáceas perenes no $2^{\circ}$ ciclo de bananeiras cultivar nanicão. Seropédica: Embrapa-CNPAB, $6 \mathrm{p}$ (Comunicado Técnico, 53).

PERIN A; LIMA EA; PEREIRA MG; TEIXEIRA MG; GUERRA JGM. 2004. Efeitos de coberturas vivas com leguminosas herbáceas perenes sobre a umidade e temperatura do solo. Agronomia 38: 27-31.

PRIMAVESI A. 2002. Manejo ecológico do solo. São Paulo: Nobel. 549p.

RIBAS RGT; JUNQUEIRA RM; OLIVEIRA FL; GUERRA JGM; ALMEIDA DL; ALVES
BJR; RIBEIRO RLD. 2003. Desempenho do quiabeiro (Abelmoschus esculentus) consorciado com Crotalaria juncea sob manejo orgânico. Agronomia 37: 80-84.

RIZZO AAN; CHIKITANE KS; BRAZ LT; OLIVEIRAAP. 2001. Avaliação de cultivares de quiabeiro em condições de primavera em Jaboticabal-SP. In: CONGRESSO BRASILEIRO DE OLERICULTURA, 41. Resumos... Brasília: SOB (CD-ROM).

SANTOS IC; MENDES FF; LIMA JS; VENZON M; PINTO CMF; SALGADO LT. 2004. Desenvolvimento de plantas de pimenta malagueta e produção de frutos em cultivo intercalar com adubos verdes anuais e perenes. In: CONGRESSO BRASILEIRO DE OLERICULTURA, 44. Resumos... Campo Grande: SOB (CD-ROM).

SANTOS CAB; ZANDONÁ SR; ESPINDOLA JAA; GUERRA JGM; RIBEIRO RLD. 2011. Efeito de coberturas mortas vegetais sobre o desempenho da cenoura em cultivo orgânico. Horticultura Brasileira 29: 103-107.

SEDIYAMA MAN; SANTOS MR; VIDIGAL SM; SALGADO LT; PEDROSA MW; JACOB LL. 2009. Produtividade e estado nutricional do quiabeiro em função da densidade populacional e do biofertilizante suíno. Bragantia 68: 913-920.

SEVERINO FJ; CHRISTOFFOLETI PJ. 2004. Weed suppression by mother crops and selective herbicides. Science Agricultural 61: 21-26.

SOUZA JL. 2003. Manual de horticultura orgânica. Viçosa: Aprenda Fácil. 564p.

SOUZA IM. 2012. Produção de quiabeiro em função de diferentes tipos de adubação. São Cristóvão: UFS. 66p (Dissertação mestrado).

STRECK NA; SCHNEIDER FM; BURIOL GA. 1994. Modificações físicas causadas pelo mulching. Revista Brasileira de Agrometeorologia 2: 131-142.

TEODORO RB; OLIVEIRA FL; SILVA DMN; FÁVERO C; QUARESMA MAL. 2011. Leguminosas herbáceas perenes para utilização como coberturas permanentes de solo na Caatinga Mineira. Revista Ciência Agronômica 42: 292-300.

TIVELLI SW; KANO C; PURQUERIO LFV; WUTKE EB; ISHIMURA I. 2011. Desempenho do quiabeiro consorciado com adubos verdes de porte baixo em cultivo orgânico. In: CONGRESSO BRASILEIRO DE OLERICULTURA, 51. Resumos... Viçosa: SOB (CD-ROM). 